\title{
RESEARCH ON RELATIONSHIP BETWEEN REGIONAL CORRUPTION AND PERFORMANCE OF LISTED COMPANIES
}

\author{
Fan Yang \\ SHU-UTS SILC Business School, Shanghai University, Shanghai Jiangong Engineering \\ Materials Co., Ltd., P.R.China \\ Haining Wu \\ SHU-UTS SILC Business School, Shanghai University, P.R.China \\ Wenjie Yang \\ SHU-UTS SILC Business School, Shanghai University, P.R.China
}

\begin{abstract}
The research aims to test the relationship between the degree of corruption and the performance of listed companies. Based on listed companies' data before and after the implementation of the "eight bans" in 2005 and 2011, we will use the method of empirical research to analyze the impact of regional corruption on the performance of listed companies. According to the nature of corruption, the analysis of the characteristics of the corruption event is carried out and the corruption variable is further explained by using the event system theory. The impact of corruption is analyzed with two dimensions of time and space, making the analysis of the impact of regional corruption on listed companies more objective and reducing the disturbance caused by other variables, reducing the error caused by the endogenous between corruption and economy. Result shows that there is a negative correlation between the intensity of corruption and the performance of listed companies. The regional differences will regulate the relationship between regional corruption and the performance of listed companies, and although the time characteristics of corruption events affect the listed companies, it has not been verified in this article.
\end{abstract}

Keywords: regional corruption, listed companies

JEL code: M38

\section{Introduction}

Many researches have shown that corruption has promotion effect on company performance. Political rent-seeking behavior can bring companies qualification to enter monopolized industries and bring companies more resources and development opportunity. Companies in administrative monopoly industries are more likely to use bribes to establish and maintain a good political connection with the administrative staffs. Companies can obtain tax incentives, reduce management and audit cost and get more orders from the government through corruption methods like bribery (Cai et al., 2011). On the other hand, corruption can help companies to shorten the cost of queuing, and can even bypass the legal and administrative control to obtain more scarce resources.

There are also many studies showing corruption's negative impact on company performance. Anti-corruption can improve business performance and the effect is more significant in areas which government intervenes seriously. Zhong et al. (2016) state that anti-corruption has had a positive impact on company performance by accelerating asset turnover, shortening 
business cycles, optimizing investment efficiency and improving production efficiency, and prove that corruption can bring negative economic effect to micro-enterprises. Corruption can also reduce the efficiency of resource allocation to a great extent. Particularly in the environment where the market mechanism is not perfect, the market openness is low, and the government power is concentrated, corruption is a kind of helpless suboptimal choice for companies.

The existing literature has made a detailed and comprehensive description of corruption, and in all studies, corruption is defined as an action out of rule and regulation. It is clear that corruption is not a reasonable behaviour. In the study of the relationship between corruption and economic development, although some studies support for corruption and state it can bring some positive benefits to economic development, more research shows that corruption is not conducive to economic development. When refining to research on micro corporate performance, there are more literature researches showing that all the impact of corruption on business performance is almost negative. In most literature, the study of corruption's impact on economic development only takes the impact of corruption into consideration. Although some researches study on the impact channel, there is still no multiple study of corruption. Therefore, in order to study the influence of regional corruption on listed companies' performance in a more comprehensive way, this paper introduces the event system theory, dividing regional corruption into three characteristic levels, and using dimensions of intensity, space and time respectively to study the impact of corruption on listed companies' performance.

\section{Literature Review}

The most popular definition of corruption at home and abroad is that corruption is the abuse of public positions to achieve the purpose of seeking personal interests (Cai 2001). World Bank defines corruption behavior as a subjective motive for personal gain to violate public power or job norms, revealing the nature of corruption more accurately (Cai 2001). Neil (1998) argues that corruption is an act of abandoning the normative duties of a public role in order to give interest, like money and identity, to private or private social circles.

Leef (1964) argues that corruption can make the inefficient and rigid regulations in government institutions become looser, which somewhat has a positive effect on economic development. Corruption reduces queuing waiting time, reduces opportunity cost of queuing, and reduces inefficiency in government administration and management. Corruption may has a positive maximum output level in the economic development. If corruption is within this level, the corruption will play a significant role in promoting economic development. Egger \& Winner (2005) studied data from 73 developed countries and developing countries, found that corruption can stimulate foreign direct investment and increase foreign investment incentives. Further research shows that bribery is a behavioral mechanism in which resources are reallocated between government agencies and enterprises. The essence of bribery is overcome the government's inefficient decision-making to do efficient decision-making redemption and enhance the economic efficiency of enterprises through rent-seeking behavior. Afterwards, many scholars have given evidence from the perspective of empirical research.

The other view is that there is a negative correlation between corruption and economic development. The test result shows that corruption will not only inhibit economic growth, but also put indirect effect on the economic development through investment, human capital, politics, market competition, and many other channels. Bardhan (1997) argues that if the cost 
of rent-seeking is higher than that of productive investment, it means that private firms use a large amount of money to bribe government officials to obtain relevant investment projects. Corruption could lead to an increase in the cost of private investment through the study of the impact of corruption on public finances. Gupta et al. (1998) argue that corruption can lead to problems such as poverty and inequality, and can make economic growth become lower.

Most Domestic scholars agree that anti-corruption can effectively improve the performance of enterprises, and this effect has a more significant response and performance in the area with serious governmental intervention. Administrative corruption led to a significant reduction in economic growth and a significant increase in public expenditure as a percentage of GDP. Chen et al. (2008) found that corruption can directly hamper economic growth and reduce economic growth rate. Li et al. (2010) found that there was a clear Kuznets curve effect in the study of the relationship between economic growth and corruption in China. The research of Zhong et al. (2016) shows that anti-corruption put a positive impact on company performance through the intermediary channels like speeding up asset turnover, shortening business cycle, optimizing investment efficiency, and improving production efficiency. And the research also proofs that corruption will bring micro-enterprises to negative economic effects.

\section{Research Hypothesis}

Event System Theory (EST) provides an integrated framework to implement bridge variance and process theory, which includes quantifiable events existing in space, time, and other events independently (Morgeson F.P. et al, 2015). EST expands the previous variance and process theory to illustrate why the intensity of events is quantified by novelty, destructive and criticality (to indicate what makes the event meaningful and influential). EST also focuses on the intensity and change of the event, and the behavior, characteristics and subsequent events created (i.e. the interaction between the amount of the given event feature and the other factors associated with the spatial and temporal factors, causing a change in the size of the organization).

On the basis of previous research, EST focuses on the key event characteristics of novelty, criticality and destructive, which provide important information about event intensity. Novelty reflects the extent to which the event is different or different from the current and past acts, features and events, thereby representing new or unexpected phenomena. Criticality reflects the importance, necessity or priority of the event to the entity, and often leads to additional analysis and changes. Destructive events may hinder or change the routines that are in progress and require entities to adjust and adapt.

\subsection{Event intensity dimension}

The interruption of events reflects the environmental discontinuity, which means the external situation has changed (Hoffman \& Ocasio, 2001). Thus, it involves variable or extent of common activities and reflects the perceived threat experienced by the main event interruption (Morgeson \& DeRue, 2006). In other words, destructive events may hinder or alter the routines that are being carried out and require entities to adjust and adapt. This requires more cautious, detailed information processing to the new behaviors, characteristics and events that change the existing behavior and characteristics. Such information processing may involve questions like 'what behavior needs to be changed?' and 'what routines or rules need to be adjusted?' 
For regional corruption, its intensity is mainly reflected in the degree of regional corruption. The degree of corruption in the area is the most direct manifestation of the rent-seeking behavior of the person involved in the crime of duty. The higher the degree of corruption in the district, the higher the number of government administrative staff in the region and the higher administrative threshold is. And the situation will be clearly reflected in the government entities and corporate entities. At the same time, the higher the degree of corruption in the region, it also shows that the closer the government's control and the right to resources allocation is, which exacerbates the government's own existence of the redundant situation, and results in lower efficiency of the administrative agencies and resource allocation. For companies, in areas where corruption is high, they need to spend more money and other resources they own to participate in the 'corruption market' competition, rather than the normal market competition. It is no doubt a substantial increase of the cost of enterprise development. Therefore, the higher the degree of corruption in the region is, the more destructive the corruption event is.

\section{Hypothesis 1: The higher the degree of corruption in the region is, the more serious the negative effect on the listed company will be.}

\subsection{Event spatiality dimension}

The greater the distance between the two organizational levels, the less likely the entity associated with one level to access the information and be affected event of other level. For example, the turnover of a production team is more likely to affect his or her team leader than the CEO. In addition to this vertical or hierarchical aspect (i.e. the number of levels between two entities), the event proximity has a horizontal component (i.e. the physical distance between two events at the same level). For example, two employees or teams may have similar levels of hierarchy, but their positions are the same in the organization chart and are physically separate (i.e. different floors, buildings).

The spatial nature of corruption is reflected in regional differences. Because of the regional differences, the spatial characteristics of regional corruption will lead to a relatively strong difference, especially in China, which has a special social context, the regional differences will lead to differences in regional corruption. For enterprises, the more intimate their relationships with the government are, the more obvious the advantages of corruption in the competition are, and the more they can obtain from improper resource allocation and improper benefits. And vice versa, for the government, the closer the relationship with the enterprise is, the more likely it is to produce the motive of corruption, but also easier to form a very strong exclusion of corruption network. This relationship is also a mechanism for distorting the corruption market. Companies and government entities in this network are more competitive in corrupt markets. And even the entity outside the network do pre-bribery or increase the amount of bribery, it may not be able to make up for its disadvantage compared with those in the network. And most of these differences are depending on the response of a region to corruption. This network is difficult to establish in regions with intense response. On the contrary, this network is easy to build in regions with less or even no response.

\section{Hypothesis 2: The spatial nature of corruption will regulate the relationship between regional corruption and the performance of listed companies.}




\subsection{Event timeliness dimension}

Activity time is limited, and this is part of distinguishing them from the longer-term characteristics of work environment. This aspect of the event raised some interesting questions about the effects of behavior, characteristics and subsequent events. The event may be temporary, but the time or scope is limited or prolonged, thus make the corresponding effect greater. The development history of an entity can play an important role in determining the impact of events. Event strength may also change over time, and the trajectory of event strength may interact with the general event intensity to influence the event outcome. It is the question of time for us to research on.

Although time is limited, difference may exist. Some events may only last for some time, while other events may continue for a while and have a greater impact. Duration may mitigate the impact of results on events. Assuming that novelty, interruption and criticality are equal, events with longer duration have more influence on organizational entities than that with shorter duration. Thus, event strength and duration may interact with each other to influence the outcome of the event.

The temporal response of corruption event is in the lasting period of corruption or anticorruption. In this research, we will take the implementation of the "eight bans" as anticorruption incident. Since the proposed time of eight ban is 2007, so year 2008 undoubtedly has the highest event time characteristics in the sample interval. The temporal characteristics of the three-year sample interval after 2008 are declining. In the study of the overall data sample, we can see that the number of job crimes in most provinces after 2008 has increased, indicating that the provinces have stepped up their crimes against duty after the implementation of the eight bans. For this phenomenon, the disclosure of the number of job crime growth in economically developed areas like Shanghai, Tianjin and Beijing is much lower than economically underdeveloped areas like Sichuan, Shandong and Hunan. And for economically backward areas like Tibet and Xinjiang, there is basically no change. And the total number of crimes committed by the number of economically underdeveloped areas is much higher than the economically developed areas and economically backward areas. In addition, the number of duty crimes in the three-year period after 2008 has shown a downward trend, but still more than the number before 2008. This is to say, the implementation of eight ban has put great impact on political environment in the most intense point of the novelty. After the period of time, although the impact still exists, it is not as strong as it is in 2008. In contrast to company performance data, we can see that the greater the volatility of corruption is, the greater the volatility of the company performance is, indicating that the degree of timeliness characteristics of corruption or anti-corruption events' impact on corporate performance entities have different intensity.

\section{Hypothesis 3: The impact of corruption on listed companies' performance will change over time.}

\section{Methods and Data}

The research emphasizes on influence of regional corruption on performance of listed companies. However, there are more variables putting influence on listed companies' performance. While measuring regional corruption, the scale of local government is a significant variable, which shows a direct relation to local economic development level. And local economic development level is connected with the performance of listed companies since the higher the local economic development level, the more attractive for companies to 
come to invest. What's more, as is mentioned before, average wage of civil servants and other industries provide motives for corruptions. So these two variables are also added into our research. Additionally, the influence of regional marketization level cannot be neglected since companies tend to have different cognition on corruption in regions with different marketization level. Finally, corruption has different influence on companies with different property rights, showing a more significant impact on state-owned enterprises than the nonstate-owned ones. So we add company property right into control variables as well. In a word, when analyzing impact of regional corruption on performance of listed companies, besides two key variables: performance of listed companies (EPS) and corruption level (Corrupt), we add some more significant variables: scale of government (Gov), local economic development level (GDP), company total assets (Size), company property rights (SOE), marketization level (Market), local average wage (HC), and region (Area).

A decision function is needed when doing quantitative inspection. Based on the variables, we create a regression function as follow:

$$
\begin{gathered}
\text { EPS }_{\text {it }}=\alpha_{0}+\alpha_{1} \text { Corrupt }_{i t}+\alpha_{2} \mathrm{GDP}_{\mathrm{it}}+\alpha_{3} \text { Size }_{\mathrm{it}}+\alpha_{4} \mathrm{SOE}_{\mathrm{it}}+\alpha_{5} \text { Market }_{\mathrm{it}}+ \\
\alpha_{6} \mathrm{HC}_{\mathrm{it}}+\alpha_{7} \mathrm{Area}_{\mathrm{it}}+\alpha_{8} \mathrm{Gov}_{\mathrm{it}}+\mu_{\mathrm{i}}
\end{gathered}
$$

\subsection{Dependent Variables and Explanation Variables}

Explained Variable:

Earnings Per Share (EPS), which is the monetary value of earnings per outstanding share of common stock for a company. The calculation function of EPS is:

$$
\text { EPS }=\text { Net Profit } / \text { Capital Stock }
$$

Explanatory Variables:

(1) Regional corruption level (Corrupt). In research and journals, there are various quantification criterions to measure corruption level. For example, in China, people tend to use expenses on recreational activities as the quantification criterion of corruption. This article uses ratio of amount of local duty-related crimes and civil servants, in the form of ' $x$ pieces per 10000 civil servants', as the quantification criterion. The data are collected from Procuratorial Yearbook of China, which is published by China Procuratorate Press.

(2) Company scale (Size). We think that performance of listed companies is related to company scale. Thus, we collected annual total assets of 858 listed companies from 2005 to 2011 from CSMAR database. In order to prevent error causing by too large data, the data will be pre-processed through natural logarithm.

(3) Region (Area). In this article, according to common region division method in China, 31 provinces are divided into 3 areas: eastern, central and western area. Eastern area includes 11 provinces, including Beijing, Tianjin, Hebei, Liaoning, Shanghai, Jiangsu, Zhejiang, Fujian, Shandong, Guangdong, and Hainan. Central area includes 8 provinces, including Heilongjiang, Jilin, Shanxi, Anhui, Jiangxi, Henan, Hubei, and Hunan. Western area includes 12 provinces, including Inner Mongolia, Guangxi, Chongqing, Sichuan, Guizhou, Yunnan, Tibet, Shaanxi, Gansu, Qinghai, Ningxia, and Xinjiang. Three dummy variables, 0,1 , and 2 , are set to correspond to three areas.

(4) Company property rights (SOE). Because of the political characteristic of corruption, we think that impact of corruption on state-owned enterprises and non-state-owned 
enterprises will be different. So companies can be divided into state-owned ones and nonstate-owned ones based on property rights. Two dummy variables, 0 and 1 , are set to correspond to two company types.

(5) Scale of government (Gov). We think that regional corruption level not only can be shown by direct data like amount of duty-related crimes, but also be impacted by government scale. In order to have an accurate application on regional data, we add the variable of government scale. The quantification standard of government scale is the ratio of annual local fiscal expenditure and local GDP.

(6) Local marketization index (Market). Marketization index refers to regional market development level. The data will be collected from Marketization Index of China's Provinces: Neri Report 2016, written by Xiaolu Wang, Gang Fan and Jingwen Yu.

(7) Local average wage (HC). Average wage is a measure for the overall wage level of regional inhabitants. The data will be collected from CSMAR database. In order to prevent error causing by too large data, the data will be pre-processed through natural logarithm.

(8) Local economic development level (GDP). Gross Domestic Product (GDP), which means the market value of all final goods and services produced in a period (quarterly or yearly), is a key measure of economic condition. The data will be collected from CSMAR database. In order to prevent error causing by too large data, the data will be pre-processed through natural logarithm.

The overall description of all variables is shown in Table 1:

Table 1: Variables Description

\begin{tabular}{c|l|l}
\hline \multicolumn{1}{c|}{ Type of Variable } & \multicolumn{1}{|c}{ Name } & \multicolumn{1}{c}{ Meaning } \\
\hline \multirow{4}{*}{$\begin{array}{c}\text { Dependent Variables } \\
\text { Earnings Per Share (EPS) }\end{array}$} & $\begin{array}{l}\text { Monetary value of earnings } \\
\text { per outstanding share of common } \\
\text { stock for a company }\end{array}$ \\
\hline \multirow{5}{*}{ Independent Variables } & Regional corruption level (Corrupt) & $\begin{array}{l}\text { Ratio of amount of local duty-related } \\
\text { crimes and civil servants }\end{array}$ \\
\cline { 2 - 3 } & Company scale (Size) & Company total assets \\
\cline { 2 - 3 } & Region (Area) & $\begin{array}{l}\text { State-owned enterprise/non-state-owned } \\
\text { enterprise }\end{array}$ \\
\cline { 2 - 3 } & Company property rights (SOE) & $\begin{array}{l}\text { Ratio of annual local fiscal expenditure } \\
\text { and local GDP }\end{array}$ \\
\cline { 2 - 3 } & Scale of government (Gov) & Regional market development level \\
\cline { 2 - 3 } & Local marketization index (Market) & $\begin{array}{l}\text { Regional industrial annual average } \\
\text { wage }\end{array}$ \\
\cline { 2 - 3 } & Local average wage (HC) & $\begin{array}{l}\text { Market value of all final goods and } \\
\text { services produced in a year }\end{array}$ \\
\cline { 2 - 3 } & $\begin{array}{l}\text { Local economic development level } \\
\text { (GDP) }\end{array}$ & \\
\hline
\end{tabular}

In order to integrate initial data collected from 31 provinces into 3 regional ones (eastern, western and central areas), the initial data are weighed and integrated. 


\subsection{Sample Selection}

The key samples come from listed companies' performance and corruption level. In this article, data about listed companies' performance are collected from CSMSR database. We collected EPS data of 858 listed companies from 2005 to 2011 as the evaluation criteria of listed companies' performance and excluded samples whose relevant independent data are not complete. Company integrated report are also used as data source to prevent errors. For corruption level, we chose Procuratorial Yearbook of China, which is published by China Procuratorate Press, as the data source. Complete data of the ratio of amount of duty-related crimes and civil servants in 31 provinces from 2005 to 2011 will be used as evaluation standard and be integrated into 3 regional data.

\subsection{Statistical Description}

The article collected data of 858 listed companies and organized them into 6006 samples. Data in non-integrated financial statement are not used. Data with incomplete information, because of company incomplete information disclosure or newly listed in 2005 to 2011, are also excluded. After data processing, each variable is analyzed by using descriptive statistics. The result of descriptive statistics is shown in Table 2:

Table 2 Descriptive Statistics

\begin{tabular}{ccccccc}
\hline Variables & $\mathrm{N}$ & MEAN & MEDIAN & MAX & MIN & Std.Err \\
\hline EPS & 6006 & 0.260 & 0.186 & 6.428 & -7.057 & 0.046 \\
Corrupt & 6006 & 24.343 & 25.009 & 32.265 & 17.661 & 3.674 \\
Size & 6006 & 21.610 & 21.535 & 28.659 & 10.842 & 1.450 \\
Area & 6006 & 0.659 & 0.000 & 2.000 & 0.000 & 0.822 \\
SOE & 6006 & 0.636 & 1.000 & 1.000 & 0.000 & 0.481 \\
Gov & 6006 & 0.275 & 0.252 & 0.490 & 0.148 & 0.094 \\
Market & 6006 & 7.723 & 7.880 & 9.491 & 4.614 & 1.596 \\
GDP & 6006 & 9.369 & 9.320 & 12.027 & 7.681 & 0.995 \\
HC & 6006 & 10.309 & 10.320 & 10.799 & 9.599 & 0.303 \\
\hline
\end{tabular}

According to the descriptive statistics, although the minimum EPS among all listed companies is -7.057 , the average of all samples is 0.186 , showing a positive value. In addition, the standard deviation of EPS is very small, showing that it has a stable fluctuation range. That is to say, in 2005 to 2011, most listed companies have positive EPS. For the other key variable, Corrupt, the standard deviation is 3.674, which is the biggest among all standard deviations, showing a high fluctuation. That is to say, corruption level has changed a lot in the period of 2005 to 2011.

\subsection{Panel Data Processing}

\subsubsection{Unit Root Test}

In order to prevent spurious regression, which may be caused by nonstationary time series and influence the accuracy of the test, the article will first do the unit root test to the dependent variable EPS. The test result is shown in Table 3:

Table 3 EPS Unit Root Test

Null Hypothesis: the variable has unit root $\operatorname{chi} 2(1716)=4329.7693$

Prob $>$ chi $2=0.0000$ 
In the processing result, $\mathrm{p}$ value is less than 0.05 , so the null hypothesis is rejected. That is to say, the variable does not have unit root and EPS is stable. At the same time, we also do the unit root test to regional corruption level (Corrupt), company scale (Size), local economic development level (GDP), local average wage (HC), local marketization index (Market). All tests do not have unit root.

For dummy variables like region (Area) and company property rights (SOE), and integrated variables like scale of government (Gov), unit root test is not suitable since huge amount of repeating data will be produced.

\subsubsection{Comparison and Choice on Regression Model}

The article uses panel data to do the regression test. Thus we will compare and choose among simple least square method (OLS), random effect model and fix effect model. After the basic regression model is decided, heteroscedasticity test and stable test will be done to the model.

Firstly, the article will compare random effect model and simple linear regression model. The regression result of random effect model is shown in Table 4:

Table 4: Regression result of random effect model

\begin{tabular}{ccccc}
\hline EPS & Coef. & Std.Err & $\mathrm{Z}$ & $\mathrm{p}>|\mathrm{Z}|$ \\
\hline Size & .1217975 & .0074929 & 16.26 & 0.000 \\
Area & .0061659 & .0508019 & 0.12 & 0.903 \\
SOE & .0192332 & .021619 & 0.89 & 0.374 \\
Gov & -.0155833 & .0028251 & -5.52 & 0.000 \\
Market & -.0112376 & .015825 & -0.71 & 0.478 \\
Corrupt & -.009136 & .005027 & -1.82 & 0.069 \\
GDP & .0252154 & .0117712 & 2.14 & 0.032 \\
HC & .0535567 & .0647027 & 0.83 & 0.408 \\
_cons & -2.855302 & .7013517 & -4.07 & 0.000 \\
sigma_u & .29335214 & & & \\
sigma_e & .49228467 & & & \\
Rho & .26204495 & & & \\
\hline
\end{tabular}

Then Breusch \& Pagan Lagrangian Multiplier test will be done to the regression result of random effect model, the function is:

$$
\operatorname{eps}\left[\mathrm{i}_{\mathrm{d}}, \mathrm{t}\right]=\mathrm{X}_{\mathrm{b}}+\left[\mathrm{i}_{\mathrm{d}}\right]+\mathrm{e}\left[\mathrm{i}_{\mathrm{d}}, \mathrm{t}\right] \text {, }
$$

The regression result is shown in Table 5: 
Table 5: Breusch \& Pagan Lagrangian Multiplier test

\begin{tabular}{ccc}
\hline & Var & sd = sqrt(Var) \\
\hline EPS & .3750423 & .612407 \\
$\mathrm{E}$ & .2423442 & .4922847 \\
$\mu$ & .0860555 & .2933521 \\
& Test: $\operatorname{Var}(\mathrm{u})=0$ & \\
& chibar2 $(01)=1222.54$ & \\
& Prob $>$ chibar2 $=0.0000$ & \\
\hline
\end{tabular}

In the test result, $\mathrm{p}$ value is less than 0.05 , so the random effect model is more significant than the simple least square method model.

After that, the article will compare fix effect model and simple least square method model. The regression result of fix effect model is shown in Table 6:

Table 6: Regression result of fix effect model

\begin{tabular}{ccccc}
\hline EPS & Coef. & Std.Err & $\mathrm{T}$ & $\mathrm{p}>|\mathrm{t}|$ \\
\hline Size & .0841034 & .0130232 & 6.46 & 0.000 \\
Area & - & - & - & - \\
SOE & - & - & - & - \\
Gov. & -.0152078 & .0028221 & -5.39 & 0.000 \\
Market & -.0079747 & .0159683 & -0.50 & 0.618 \\
Corrupt & -.0251175 & .0077713 & -3.23 & 0.001 \\
GDP & .0206972 & .0119161 & 1.74 & 0.082 \\
HC & -.0308806 & .0796261 & -0.39 & 0.698 \\
cons & -.7375091 & .9532597 & -0.77 & 0.439 \\
sigma_u & .35983922 & & & \\
sigma_e & .49228467 & & & \\
Rho & .34823656 & & Prob $>\mathrm{F}=0.0000$ & \\
\multicolumn{2}{c}{ F test that all u_i=0: } & $\mathrm{F}(857,5141)=$ & 3.51 &
\end{tabular}

In the test result, $\mathrm{p}$ value is less than 0.05 , so the fix effect model is more significant than the simple least square method model.

Finally the article will compare fix effect model and random effect model. The Hausman test result of fix effect model and random effect model is shown in Table 7:

Table 7: Hausman Test Result

\begin{tabular}{|c|c|c|c|c|}
\hline & \multicolumn{4}{|c|}{ Coefficients } \\
\hline & (b) & (B) & (b-B) & $\operatorname{sqrt}\left(\operatorname{diag}\left(\mathrm{V} \_b-\mathrm{V} \_B\right)\right)$ \\
\hline & $\mathrm{Fe}$ & $\mathrm{Re}$ & Difference & S.E. \\
\hline Size & .0841034 & .1217975 & -.037694 & .0106518 \\
\hline Gov & -.0152078 & -.0155833 & .0003756 & .0011356 \\
\hline Market & -.0079747 & -.0112376 & .0032628 & .0021343 \\
\hline Corrupt & -.0251175 & -.009136 & -.0159815 & .0059265 \\
\hline GDP & .0206972 & .0252154 & -.0045182 & .0018529 \\
\hline \multirow[t]{2}{*}{$\mathrm{HC}$} & -.0308806 & .0535567 & -.0844373 & .04641 \\
\hline & \multicolumn{4}{|c|}{$\begin{array}{c}\text { Test: Ho: difference in coefficients not systematic } \\
\text { chi2 }(6)=(b-B)^{\prime}\left[\left(V \_b-V \_B\right)^{\wedge}(-1)\right](b-B)=18.33 \\
\text { Prob }>\text { chi } 2=0.0055\end{array}$} \\
\hline
\end{tabular}


$\mathrm{P}$ value is smaller than 0.05 , showing that the evaluation data do not meet the hypothesis that Hausman test needs. Thus we reject the null hypothesis and hold that the fix effect model is better than the random effect model.

\subsubsection{Heteroscedasticity Test}

In fix effect model, one of the basic hypotheses is homosecdasticity. Random error should meet homosecdasticity. That is to say, random error $\mu_{1}$ should be the same constant in different observed values. To ensure the accuracy of regression result, the article will do heteroscedasticity test to regression result of the fix effect model. The test result is shown in Table 8:

Table 8: Heteroscedasticity Test Result

\begin{tabular}{c}
\hline Null Hypothesis: Random error meets homosecdasticity \\
\hline $\operatorname{chi} 2(858)=1.4 \mathrm{e}+06$ \\
Prob $>$ chi $2=0.0000$ \\
\hline
\end{tabular}

In the test result, $\mathrm{p}$ value is smaller than 0.05 , so null hypothesis is rejected. That is to say, the panel data used in fix effect model regression test has significant heteroscedasticity. Thus we should focus more on controlling heteroscedastcity when modeling. The regression result is in Table 9:

Table 9: Fix Effect Model Regression Result after Controlling Heteroscedastcity

\begin{tabular}{ccccc}
\hline EPS & Coef. & Std.Err & $\mathrm{T}$ & $\mathrm{p}>|\mathrm{t}|$ \\
\hline Size & .0841034 & .0430466 & 1.95 & 0.051 \\
Area & - & - & - & - \\
SOE & - & - & - & - \\
Gov & -.0152078 & .0028642 & -5.31 & 0.000 \\
Market & -.0079747 & .0181284 & -0.44 & 0.660 \\
Corrupt & -.0251175 & .0078194 & -3.21 & 0.001 \\
GDP & .0206972 & .0092618 & 2.23 & 0.026 \\
HC & -.0308806 & .1032542 & -0.30 & 0.765 \\
cons & -.7375091 & 1.031827 & -0.71 & 0.475 \\
sigma_u & .35983922 & & & \\
sigma_e & .49228467 & & & \\
Rho & .34823656 & & & \\
\hline
\end{tabular}

\subsection{The impact of corruption intensity on listed companies' performance - based on panel data}

Finally we will do the regression test to the basic regression function that we set before. The regression result is shown in Table 10. In the result table, Regression 1 is the Pooled simple least square method model (Pooled OLS), Regression 2 is the progressive fix effect model, Regression 3 is the fix effect model which controlling heteroscedastcity, and Regression 4 is the random effect model. 
Table 10: Regression Result and Robustness Test on Corruption Level

\begin{tabular}{|c|c|c|c|c|}
\hline \multirow{3}{*}{$\begin{array}{l}\text { Independent } \\
\text { Variables }\end{array}$} & \multicolumn{4}{|c|}{ Dependent Variable - EPS } \\
\hline & Regression 1 & Regression 2 & Regression 3 & Regression 4 \\
\hline & $\begin{array}{l}\text { Coefficient } \\
\text { (std) }\end{array}$ & $\begin{array}{c}\text { Coefficient } \\
\text { (std) }\end{array}$ & $\begin{array}{l}\text { Coefficient } \\
\text { (std) }\end{array}$ & $\begin{array}{l}\text { Coefficient } \\
\text { (std) }\end{array}$ \\
\hline Corrupt & $\begin{array}{c}-0.00512 \\
(.0065614)\end{array}$ & $\begin{array}{l}-0.0251^{* *} \\
(.009405)\end{array}$ & $\begin{array}{l}-0.0251^{* * *} \\
(.0078194)\end{array}$ & $\begin{array}{l}-0.00914^{*} \\
(.005027)\end{array}$ \\
\hline Area & $\begin{array}{c}-0.00267 \\
(.0575048)\end{array}$ & & & $\begin{array}{c}0.00617 \\
(.0508019)\end{array}$ \\
\hline SOE & $\begin{array}{c}0.0255 \\
(.0215262)\end{array}$ & $\begin{array}{c}-0.601 \\
(1.363661)\end{array}$ & & $\begin{array}{c}0.0192 \\
(.021619)\end{array}$ \\
\hline Gov & $\begin{array}{l}-0.0157^{* * * *} \\
(.0039934)\end{array}$ & $\begin{array}{l}-0.0152^{* * * *} \\
(.0035017)\end{array}$ & $\begin{array}{l}-0.0152^{* * * *} \\
(.0028642)\end{array}$ & $\begin{array}{l}-0.0156^{* * * *} \\
(.0028251)\end{array}$ \\
\hline Market & $\begin{array}{c}-0.0119 \\
(.0186967)\end{array}$ & $\begin{array}{c}-0.00797 \\
(.0143741)\end{array}$ & $\begin{array}{c}-0.00797 \\
(.0181284)\end{array}$ & $\begin{array}{c}-0.0112 \\
(.015825)\end{array}$ \\
\hline Size & $\begin{array}{c}0.133^{* * * *} \\
(.0067321)\end{array}$ & $\begin{array}{c}0.0841 \\
(.0509526)\end{array}$ & $\begin{array}{c}0.0841^{*} \\
(.0430466)\end{array}$ & $\begin{array}{c}0.122^{* * * *} \\
(.0074929)\end{array}$ \\
\hline GDP & $\begin{array}{c}0.0262^{* *} \\
(.0101275)\end{array}$ & $\begin{array}{c}0.0207^{* *} \\
(.008055)\end{array}$ & $\begin{array}{c}0.0207^{* *} \\
(.0092618)\end{array}$ & $\begin{array}{c}0.0252^{* *} \\
(.0117712)\end{array}$ \\
\hline $\mathrm{HC}$ & $\begin{array}{c}0.0734 \\
(.0879198)\end{array}$ & $\begin{array}{c}-0.0309 \\
(.098831)\end{array}$ & $\begin{array}{c}-0.0309 \\
(.1032542)\end{array}$ & $\begin{array}{c}0.0536 \\
(.0647027)\end{array}$ \\
\hline _cons & $\begin{array}{c}-3.399^{* *} \\
(1.158866)\end{array}$ & $\begin{array}{c}-1.879^{*} \\
(.9532597)\end{array}$ & $\begin{array}{c}-0.738 \\
(1.031827)\end{array}$ & $\begin{array}{c}-2.855^{* * *} \\
(.7013517)\end{array}$ \\
\hline$N$ & 6005 & 6005 & 6005 & 6005 \\
\hline
\end{tabular}

Note: $* * *, * *, *$ express significance at $1 \%, 5 \%$ and $10 \%$ level respectively

The regression result in Table 10 explains the regression test result between independent variables and dependent variable EPS.

(1) The key variable corruption (Corrupt) has significant negative relevance relationship with EPS. In the fix effect model, the relationship is significant at $1 \%$ statistical level, which means corruption will put negative impact on listed companies' performance.

(2) Relationship between region (Area) and company property rights (SOE) cannot be found because of fix effect model's defect in processing dummy variables.

(3) Government scale (Gov) has significant negative relevance relationship with EPS and the relationship is significant at $1 \%$ statistical level. That is to say, government scale (Gov) has a very significant impact on company EPS. The bigger the government scale is, the greater control it has on resource allocation, and it will have negative effect to company performance.

(4) The relationship between local marketization index (Market) and EPS is not significant.

(5) Company scale (Size) has very significant positive relationship with EPS. That is to say, the bigger the company scale is, the better the company performance will be. Although this judgment is not so current, companies with bigger scale have better ability to get 
access to resource and capital, and can have bigger market share. These will make positive impact on company performance.

(6) Regional GDP (GDP) has positive relationship with EPS. If regional GDP is high, regional resource may be more abundant and regional market may have bigger scale. These will make positive impact on company performance.

(7) The relationship between local average wage (HC) and EPS is not significant.

\subsection{The impact of corruption spatiality on listed companies' performance - based on panel data}

In order to examine if the spatiality of corruption will influence corruption's impact on listed companies' performance, firstly we will do preprocessing to corruption variables and areas and get cross term $\mathrm{A}^{*} \mathrm{C}$. If the regression result is significant, the spatiality of corruption do influence corruption's impact on listed companies' performance. We still do regression test according to panel data analyzing method. The regression result is shown in Table 11. In the result table, Regression 1 is the Pooled simple least square method model (Pooled OLS), Regression 2 is the progressive fix effect model, Regression 3 is the fix effect model which controlling heteroscedastcity, and Regression 4 is the random effect model. 
Table 11: Regression Result on Corruption Spatiality

\begin{tabular}{|c|c|c|c|c|}
\hline \multirow{3}{*}{$\begin{array}{c}\text { Independent } \\
\text { Variables }\end{array}$} & \multicolumn{4}{|c|}{ Dependent Variable - EPS } \\
\hline & Regression 1 & Regression 2 & Regression 3 & Regression 4 \\
\hline & $\begin{array}{c}\text { Coefficient } \\
(\text { std })\end{array}$ & $\begin{array}{c}\text { Coefficient } \\
\text { (std) }\end{array}$ & $\begin{array}{c}\text { Coefficient } \\
\text { (std) }\end{array}$ & $\begin{array}{c}\text { Coefficient } \\
(\mathrm{std})\end{array}$ \\
\hline $\mathrm{A}^{* \mathrm{C}}$ & $\begin{array}{l}0.00805^{* * *} \\
(.0011118)\end{array}$ & $\begin{array}{c}-0.00716 \\
(.0077375)\end{array}$ & $\begin{array}{c}-0.00716 \\
(.0078047)\end{array}$ & $\begin{array}{c}0.00719^{* *} \\
(.0035771)\end{array}$ \\
\hline Corrupt & $\begin{array}{c}-0.00522 \\
(.0110569)\end{array}$ & $\begin{array}{c}-0.0224^{*} \\
(.0102539)\end{array}$ & $\begin{array}{l}-0.0224^{* * *} \\
(.0070102)\end{array}$ & $\begin{array}{c}-0.00644 \\
(.006437)\end{array}$ \\
\hline Area & $\begin{array}{c}-0.153^{* * * *} \\
(.0402271)\end{array}$ & & & $\begin{array}{c}-0.139^{*} \\
(.0836264)\end{array}$ \\
\hline Size & $\begin{array}{c}0.132^{* * * *} \\
(.0076316)\end{array}$ & $\begin{array}{c}0.0808 \\
(.0522751)\end{array}$ & $\begin{array}{c}0.0808^{*} \\
(.0432144)\end{array}$ & $\begin{array}{c}0.120^{* * *} \\
(.0075718)\end{array}$ \\
\hline SOE & $\begin{array}{c}-0.0300 \\
(.0416085)\end{array}$ & & & $\begin{array}{c}-0.0203 \\
(.0253873)\end{array}$ \\
\hline Gov & $\begin{array}{c}0.285 \\
(.2078001)\end{array}$ & $\begin{array}{c}0.187 \\
(.2028693)\end{array}$ & $\begin{array}{c}0.187 \\
(.1796056)\end{array}$ & $\begin{array}{c}0.274 \\
(.1672588)\end{array}$ \\
\hline Market & $\begin{array}{c}0.0176 \\
(.0243394)\end{array}$ & $\begin{array}{c}0.0416 \\
(.038993)\end{array}$ & $\begin{array}{c}0.0416^{*} \\
(.0241886)\end{array}$ & $\begin{array}{c}0.0180 \\
(.0171698)\end{array}$ \\
\hline gdp & $\begin{array}{c}0.0117 \\
(.0086428)\end{array}$ & $\begin{array}{c}0.0190^{* *} \\
(.0064721)\end{array}$ & $\begin{array}{c}0.0190^{* *} \\
(.0095549)\end{array}$ & $\begin{array}{c}0.0122 \\
(.0123524)\end{array}$ \\
\hline hc & $\begin{array}{c}0.133 \\
(.1660445)\end{array}$ & $\begin{array}{c}-0.0527 \\
(.1948346)\end{array}$ & $\begin{array}{c}-0.0527 \\
(.1262112)\end{array}$ & $\begin{array}{c}0.131 \\
(.0874012)\end{array}$ \\
\hline _cons & $\begin{array}{c}-4.168^{*} \\
(1.997895)\end{array}$ & $\begin{array}{c}-0.842 \\
(2.647838)\end{array}$ & $\begin{array}{c}-0.842 \\
(1.312406)\end{array}$ & $\begin{array}{c}-3.871^{* * * *} \\
(.8892735)\end{array}$ \\
\hline$N$ & 6006 & 6006 & 6006 & 6006 \\
\hline
\end{tabular}

Note: $* * *, * * *$ express significance at $1 \%, 5 \%$ and $10 \%$ level respectively

According to the regression result, cross item $\mathrm{A}^{*} \mathrm{C}$ is significant in Regression 1 and 4 . In pooled simple least square method model, the relationship is significant at $1 \%$ statistic level, which means the spatiality of corruption do influence corruption's impact on listed companies' performance.

\subsection{The impact of corruption timeliness on listed companies' performance - based on cross-sectional data}

In order to examine if the timeliness of corruption will influence corruption's impact on listed companies' performance, the article does tests respectively on data in the time period that "Eight Bans" was put forward and put into practice. The "Eight Bans" has greatest timeliness impact in 2008, and the impact became weaker gradually after 2008 to 2011 . Finally we will do tests according to cross-section data test method. The test result is shown in Table 12. 
Table 12: Corruption Timeliness Regression Result

\begin{tabular}{|c|c|c|c|c|}
\hline \multirow{3}{*}{$\begin{array}{c}\text { Independent } \\
\text { Variables }\end{array}$} & \multicolumn{4}{|c|}{ Dependent Variable - EPS } \\
\hline & 2008 & 2009 & 2010 & 2011 \\
\hline & $\begin{array}{l}\text { Coefficient } \\
\text { (std) }\end{array}$ & $\begin{array}{l}\text { Coefficient } \\
\text { (std) }\end{array}$ & $\begin{array}{l}\text { Coefficient } \\
\text { (std) }\end{array}$ & $\begin{array}{l}\text { Coefficient } \\
\text { (std) }\end{array}$ \\
\hline Corrupt & $\begin{array}{l}-0.000661 \\
(.0059834)\end{array}$ & $\begin{array}{l}0.00378 \\
(.00886)\end{array}$ & $\begin{array}{c}0.00449 \\
(.0070674)\end{array}$ & $\begin{array}{l}0.0000760 \\
(.0078472)\end{array}$ \\
\hline SOE & $\begin{array}{c}-0.0324 \\
(.0420685)\end{array}$ & $\begin{array}{l}-0.0998^{* *} \\
(.039323)\end{array}$ & $\begin{array}{c}-0.0657^{*} \\
(.0361023)\end{array}$ & $\begin{array}{c}-0.125^{* *} \\
(.048455)\end{array}$ \\
\hline Market & $\begin{array}{c}0.0114 \\
(.0138419)\end{array}$ & & & $\begin{array}{c}0.0113 \\
(.0138149)\end{array}$ \\
\hline Size & $\begin{array}{c}0.0841^{* * * *} \\
(.0138912)\end{array}$ & $\begin{array}{c}0.133^{* * *} \\
(.0124797)\end{array}$ & $\begin{array}{c}0.148^{* * *} \\
(.0111347)\end{array}$ & $\begin{array}{c}0.147^{* * * *} \\
(.1470605)\end{array}$ \\
\hline _cons & $\begin{array}{c}-1.648^{* * * *} \\
(.3391352)\end{array}$ & $\begin{array}{c}-2.722^{* * * *} \\
(.3664663)\end{array}$ & $\begin{array}{c}-2.996^{* * * *} \\
(.2880753)\end{array}$ & $\begin{array}{c}-2.863^{* * * *} \\
(.3725094)\end{array}$ \\
\hline$N$ & 858 & 858 & 858 & 858 \\
\hline
\end{tabular}

Note: $* * *, * *, *$ express significance at $1 \%, 5 \%$ and $10 \%$ level respectively

According to the regression result, all data test results from 2008 to 2011 are not significant. However, from the coefficient we can find that in 2008, which is the year that "Eight Bans" has the greatest timeliness impact, the corruption coefficient is the smallest and the corruption is negative related to listed companies' performance. In the following years, the corruption coefficient shows an increasing trend. Through observing the corruption timeliness's impact on corruption coefficient, we can still state that the hypothesis of corruption timeliness put impact on listed companies' performance.

\section{8. $\quad$ Result}

Table 13: Hypothesis Examination Result

\begin{tabular}{|c|c|c|}
\hline Number & Hypothesis Content & Result \\
\hline Hypothesis 1 & $\begin{array}{l}\text { The higher the degree of corruption in the region is, the more serious the negative } \\
\text { effect on the listed company will be. }\end{array}$ & Proved \\
\hline Hypothesis2 & $\begin{array}{l}\text { The spatial nature of corruption will regulate the relationship between regional } \\
\text { corruption and the performance of listed companies. }\end{array}$ & Proved \\
\hline Hypothesis 3 & The impact of corruption on listed companies' performance will change over time. & $\begin{array}{c}\text { Not } \\
\text { Proved }\end{array}$ \\
\hline
\end{tabular}

From the test result we can find that, corruption has significant negative relationship with listed companies' performance. In the fix effect model test, listed companies' performance will change by -0.00251 when corruption level improve by 1 point. In the progressive fix effect model test, listed companies' performance will change by -0.00251 when corruption level improve by 1 point. In the random effect model test, listed companies' performance will change by -0.00914 when corruption level improve by 1 point. That is to say, when other variables are controlled, corruption's impact on listed companies' performance will be larger when regional corruption level is higher. Thus hypothesis 1 is proved. In addition, comparing with other variables with significant relationship, such as company assets, GDP and government scale, corruption has less impact to listed companies' performance. That is to say, the impact of corruption on listed companies' performance is a long term process. The impact 
will not be great when in the short term since the impact may be covered by other variables' impact. However in the long term accumulation, the impact cannot be ignored. In all, we can reach the conclusion that the null hypothesis, corruption has negative impact on listed companies' performance, is correct. The impact will be expressed in long term.

What's more, hypothesis 2 is proved, showing that spatiality of corruption will influence corruption's impact on listed companies' performance. Corruption's impact on listed companies' performance is different in different regions. This kind of adjusting effect can be improved when regional division is more specific.

Although hypothesis 3 has not been proved, some conclusions can be found from regression coefficients. When anti-corruption regulations have been put forward firstly, the relationship coefficient between regional corruption level and listed companies' performance is very low. As the time goes, the impact of anti-corruption regulations becomes weak and the relationship coefficient shows an improving trend, showing that regional corruption's impact on listed companies' performance is increasing year by year. Thus, although the corruption timeliness cannot be proved in this research project, hypothesis 3 still has its research significance.

\section{Discussion and Conclusion}

This article uses regional corruption as external impact event to study its impact on listed companies. The impact of regional corruption level on companies' performance cannot be generalized. Many scholars states that corruption has positive impact on company performance. However, some scholars state a negative one. When studying corruption's impact on listed companies' performance, there will not be significant variance in different research samples and time periods.

In this research, we can find that the influence of corruption on listed companies' performance is complex. The influence is different in different time periods and samples. In the short term, since anti-corruption regulation is put forward and changes governments' allocation method and amount in resource, the impact will make listed companies' performance decline in short period. This kind of performance decline is not caused by companies' bad business, but caused by the adjustment of administrative agency behavior. Listed companies are forced to compete in common market again instead of 'corruption market'. Thus, although anticorruption will lead to performance decline in short term, it cannot state that corruption has positive impact on listed companies' performance. It also cannot state that anti-corruption will lead to economy decline.

However in the long term, anti-corruption can improve the efficiency of government administration, making the efficiency of government administrative agencies improve significantly. At the same time, anti-corruption can enhance the government's rationality and fairness in resource allocation, which will further affect the market, lead the market competition from the 'corruption competition' to a benign one and promote listed companies invest more resource and funds into their own development. In this case, the performance of listed companies will show a rising trend, which is a long and slow one, and government decisions will show a strong response to it.

In general, the impact of corruption on listed companies' performance presents an inverted U shape, and the response to this effect is not symmetrical on two sides of the boundary. No matter it is the state or the enterprise, it is essential to consider long-term goals instead of 
short term immediate benefits when making development decisions. That is to say, 'Effective Corruption' is not a correct and sustainable decision. When marketization level is low, although corruption can bring short-term immediate benefits, with the trend of economic globalization and national market reforms, the pace of marketization cannot be stopped. Then the corruption's 'lubricant' effect will be weakened to a great extent. Corruption will only bring negative effects to economic development when market competition occupies the main position.

Compared with other research topics, this article is innovative in following three aspects:

(1) Use ratio of amount of local duty-related crimes and civil servants as the quantification criterion of 'corruption'. Because of the strong political nature of corruption and high typicality of the found data, we first analyze based on event intensity, then control the local administrative agency scale to further quantify the variable 'corruption'. In this way, the quantification of 'corruption' in various regions can be more objective, the universality of quantified variables are enhanced and the relationship between data and corruption events are becoming more directly and accurate.

(2) Since there is an endogenous relationship between corruption and economic development, in places where economic development is low, it is possible that regional economic will rise suddenly because of the occurrence of corruption events and decline suddenly when the corruption is over. On the contrary, in places where economic development is high, corruption's impact on regional economic will not be intense, unless the corruption intensity is very high, because the regional economy is in good condition. This kind of endogenous relationship may lead to distortion of the conclusion. This research solves this problem in both horizontal and vertical directions. First, regions with similar economic conditions in spatiality are compared. Then company performances in different timeliness period are compared.

(3) This article used event system theory to study corruption events. In the past literature researches, the study of corruption most focus on its impact on economy and its quantification method. Based on the nature of corruption, this article uses event analyzing method to analyze the characteristic of corruption events and further explain the corruption variable. Thus, the result of the hypothesis test is effective and logical. The logic weakness led by only using qualitative or quantitative analysis is avoided, so the conclusion is more convincing.

\section{References}

Allen, F., J. Qian, and M. J. Qian (2005) "Law, Finance, and Economic Growth in China", Journal of Financial Economics, pp. 57-116.

Abbott, A. (1984) "Event sequence and event duration: colligation and measurement", Historical Methods: A Journal of Quantitative \& Interdisciplinary History, vol. 17, no. 4, pp. 192-204.

Bai, J., Yang, Y. T. and Jin, D. Y. (2003) "China's current anti-corruption struggle of the quantitative analysis", Journal of Yanshan University, no. 8, pp. 38-41. 
Cai, H. F., Xu, H. G. and Colin, L. (2011) "Eat, Drink, Firms and Governments : An Investigation of corruption from Entertainment Expenditures in Chinese Firms", Journal of Law and Economics, p. 54, pp. 55-78.

Cai, C.C. (2001) "the Definition and Classification of Corruption", Journal of Chinese Youth Political Review, 20(2)pp.48-52.

Central Compilation and Translation Bureau (1972), Selected Works of Marx and Engels (Volume 1), Beijing: People's Publishing House.

Chen, K. X. (1994) "Anti-corruption must be drastic - an interview with the famous economist Professor Wu Jinglian”, Xinhua digest, no. 1, p. 25.

Chen G., Li S., Yin X.G. (2008) "Corruption and Growth of Chinese Economy- an Empirical Research" Comparative Economic and Social Systems", no. 3, pp.59-68.

Dang, L., Yang, R. L. and Yang, J. D. (2015) “Anti-corruption and enterprise innovation: based on the interpretation of political association", Enterprise Management, no. 6, pp. 146-160.

Djankov, S., Hart, O., McLiesh, C. and Shleifer, A. (2008) "Debt Enforcement around the World", Journal of Political Economy, pp. 1105-1149.

Egger P. and Wineer H. (2006) "How Corruption Influence Foreign Direct Investment: a Panel Data Study", Economic Development and Culture Change, no. 2, pp.459-486.

Edwards, J. R. (2008) "Person-environment fit in organizations: An assessment of theoretical progress", Academy of Management Annals, no. 2, pp. 167-230.

Fernandes, N., Lel, U. and Miller, D. P. (2010) "Escape From New York: the Market Impact of Loosening Disclosure Requirements", Journal of Financial Economics, pp. 129-147.

Gu, Y. Y. (2011) "Rent-seeking behaviour and loss of R \& D subsidy efficiency", Economic Science, pp. 91-103.

Hoffman, A. J. and Ocasio, W. (2001)," Not all events are attended equally: Toward a middle-range theory of industry attention to external events." Organization Science, no. 12 , pp. 414-434.

Jiang, Q. (2014) "Corruption and the growth of Chinese economy - study on the social basis of corruption governance", Journal of Nanjing Normal University, no. 3, pp. 5264.

Li, H. Q. (2008) "Building of China's clean government evaluation system”, Northeast Normal University.

Li, G. Z., Chen, H.W. and Guo, P. (2010), "the Kuznets Curve Effect of Chinese Economic Growth and Corruption", Finance and Trade Research, no.1, pp.65-70. 
Leff, N.H. (1964) "Economic Development through Bureaucratic Corruption", American Behaviour Scientist, no. 8, vol. 2, pp. 8-14.

Lin, Z. J. (2014) "Study on Bribery crime elements", East China University of Political Science and Law.

Liu, B. J. (2014) "Empirical study on the relationship between Corruption and Economic Growth", Southwest University of Finance and Economics.

Liu, C. (1997) "The struggle related to the party and the country - on the significance of anti-corruption", Workers Daily, 1997.12.22, p. 1.

Morgeson, F. P., De Rue, D. S. (2006)" Event Criticality Urgency and Duration: Understanding How Events Disrupt Teams and Influence Team Leader Intervention." Leadership Quarterly, no.17, pp. 271-287.

Morgeson, F.P., Mitchell, T.R. and Liu, D. (2015) "Event System Theory: An EventOriented Approach to the Organizational Sciences", Academy of Management Review, pp. 515-537.

Paul, H. (1998) "Political Corruption: Problems and Perspectives", Marxism and Reality, no. 6, p. 29.

Ran, Y. P. (2012) "Official corruption on corporate tax and corporate value", Chongqing University.

Samuel, H. (1998) Political order in the changing society, Beijing: Huaxia Publishing House.

Shen, Y. and Zhao, J. M. (2016) "Study on 'Being' and 'Loss' of Eating and Drinking Costs - Based on the Research on the Efficiency of Investment and Financing of Listed Companies", Finance Research, no. 11, pp. 140-156.

Tang, J. (2001) "Corruption: An Empirical Study of International Experiences - How International Transparency Organization Quantifies Integrity Index”, Theory and Reform, no. 1, pp. 5-8.

Wang, H. B. (2013) "Corruption and Economic Growth: China's provincial data test", Southwest University of Finance and Economics.

Wu, Y. P. and Rui, R. (2010) "Regional Corruption, Marketization and China's Economic Growth", Management of the World, pp. 10-27.

Xu, W. Y. (2014) “Innovation State-owned Enterprise Leaders' economic Responsibility Audit Content in Anti-corruption Advocacy Environment", Guangxi University of Finance and Economics, no. 12, pp. 128-132.

Yang, L. (2016) "Structural Governance and model of Commercial Anti-corruption", Research on Chinese Law, no. 5, pp. 110-131. 
Ye, K. T. and Zang, W. J. (2016) "External Supervision and Enterprise Cost Classification Manipulation", Management of the world, pp. 121-138.

Ying, Q. W., Liu, J. S. and Zhang, Y. (2016) "Anti-corruption and Corporate Value Evidence of Anti-corruption from the 18th National Congress of the Communist Party of China", World Economic News, no. 6, pp. 42-64.

Zeng, F. X. (2011) "Anti-corruption is an important way to ensure the development of enterprises”, Enterprise Science and Technology and Development, no. 11, pp. 117119.

Zhong, Q. L., Lu, Z. F. and Yuan, C. (2016) "Study on Anti-Corruption, Firm Performance and Its Channel Effect - A Study Based on the Anti-corruption Construction of the 18th National Congress of the CPC", Finance Research, no. 9, pp. 167-176. 